\title{
Efficiency of intensification of technique of growing winter wheat in Western Forest-steppe
}

\author{
Polovyi V. ${ }^{1}$, Lukashchuk L. ${ }^{2}$, Huk L. ${ }^{3}$
}

Institute of agriculture of Western Polissya of NAAS, Rivnenska Str., 5, Shubkov, Rivne region, Rivne oblast, 35325, Ukraine; e-mail: ${ }^{1-3}$ rivne_apv@ukr.net

The purpose. To determine effect of factors of intensification of technique of growing winter wheat both separately, and at their complex application on productivity of grain and economic efficiency. Methods. Field, laboratory-analytical and mathematical-statistical. Results. Results are generalized of long-term researches $(1991-2018)$ in technique of growing winter wheat in conditions of Rivne region on typical superficial low humus chernozem. It is determined that for modern grades of winter wheat it is necessary to apply high-intensity and high technology technique of growing. On the average for 2016-2018 the highest productivity of grain of winter wheat $-8,31,8,03,7,79,7,67$ and 7,63 t/hectare was gained accordingly at grades Krayevyd, Shchedrist Odeska, Mudrist Odeska, Astart and Ekonomka. In connection with processes of global warming of climate the optimum terms of sowing were moved from 15-25.09 in 80 - 90th years of XX century to $25.09-5.10$ in the beginning of XXI century. Implementation of potential of modern grades causes increased removal by crop from soil not only nitrogen, phosphorus and potassium, but also other nutrients. Addition into traditional fertilizer for winter wheat of magnesium, sulfur and microelements provided growth of productivity of grain on $14 \%$. Treatment of growing plants has provided with insecticide increased productivity for $16,2 \%$, and with insecticide and fungicides - for $37 \%$. Conclusions. Complex application in technique of growing of winter wheat of factors of intensification (high-yielding varieties, fertilizer system with addition of sulfur, magnesium and microelements, integrated crop protection) raised productivity of grain up to 7 t/hectare and profit - to $14144 \mathrm{hrn} / \mathrm{hectare}$.

Key words: winter wheat, technique, grade, fertilizers, terms of sowing, protection of plants, economic efficiency.

\section{https://doi.org/10.31073/agrovisnyk201811-05}

Winter wheat is the main food crop in Ukraine [1, 2, 3, 4]. Further growth of its yield and grain quality requires continuous improvement of the technology of wheat cultivation and increasing its latest scientific developments $[5,6,7,8,9]$.

The yield of winter wheat may exceed $10 \mathrm{t} / \mathrm{ha}$ in the Western Forest-steppe, which is characterized by a better moisture conditions than other regions [10]. The main factors of the intensification of its production are the use of high-quality varieties, high-quality seeds, balanced fertilizers, a wide range of means of protection from weeds, pests and diseases, growth regulators, perfect technique and, if necessary, melioration. All these factors are high-cost resources. The main task of agrarian science is based on the modeling of highly effective technologies that would ensure not only high grain yield and its quality, and would be highly profitable and environmentally safe.

The solution of these tasks requires constant updating of knowledge about the biological needs of new varieties and the possibility of their provision by the optimization of cultivation technologies.

At the Institute of Agriculture of Western Polissia of NAAS, according to the results of the conducted research, significant volumes of data were obtained, which allow to significantly increasing the efficiency of winter wheat cultivation in the region.

The purpose of the research is to determine the influence of factors of intensification of the technology of winter wheat cultivation both separately and at their complex application on grain yield and economic efficiency of its production.

Materials and methods of research. Field experiments were carried out during 1991-2018 on shallow low-humic chernozem typical. The registration area of the experimental field is $50 \mathrm{~m}^{2}$, replication is the three-stage. The technology of winter wheat cultivation, besides the investigated elements, was generally accepted for this zone. 
In addition to field researches, conducted laboratory-analytical and mathematical-statistical research on the adopted methods.

The results. The breeding of high yielding varieties which resistant to lodging, capable of providing a high return on the factors of intensification is the main prerequisite of the creation and rapid spread of intensive technology of winter wheat cultivation.

On average, in Ukraine, its yield does not exceed 4.0-4.5 t/ha, although the potential of modern varieties is much higher (table 1).

1. Yield of winter wheat varieties in the conditions of the Western Forest-steppe (average for 2015-2018)

\begin{tabular}{|l|c|c|c|}
\hline \multirow{2}{*}{ Variety } & \multirow{2}{*}{ Yield, t/ha } & \multicolumn{2}{c|}{ Increase in yield } \\
\cline { 3 - 4 } & & t/ha & $\%$ \\
\hline Poliska 90 & & - & - \\
\hline Kraievid & 6,47 & 1,84 & 28,4 \\
\hline Voloshkova & 8,31 & 0,61 & 9,4 \\
\hline Economka & $7,08^{*}$ & 1,16 & 17,9 \\
\hline Mudrist odeska & $7,63^{*}$ & 1,32 & 20,4 \\
\hline Shchedrist odeska & 7,79 & 1,56 & 24,1 \\
\hline Lira odeska & 8,03 & 1,03 & 15,9 \\
\hline Hurt & 7,50 & 1,09 & 16,9 \\
\hline Astarta & 7,56 & 1,20 & 18,6 \\
\hline Kalancha & $7,67^{*}$ & 0,16 & 2,5 \\
\hline Yuvivata 60 & $6,63^{*}$ & 0,49 & 7,6 \\
\hline Shchedra nyva & 6,96 & 1,15 & 17,8 \\
\hline
\end{tabular}

Note: * - the average is 2 years.

The results of the research indicate that the highest yields at the level of 8.31, 8.03, 7.79, 7.67 and $7.63 \mathrm{t} / \mathrm{ha}$ were provided by varieties of Kraievid (NSC "Institute of Agriculture of NAAS"), Shchedrist odeska, Mudrist odeska (Selectively Genetic Institute - NCSGS of NAAS), Astarta (Institute of Plant Physiology and Genetics of National Academy of Sciences), Economka (Myroniv Institute of Wheat named after V.M. Remeslo of NAAS), respectively.

It is important to note that due to the processes of global warming, both Western European and Southern ecotypes of varieties provide high productivity.

Given the significantly lower average wheat yields in production conditions compared to those achieved in the experiments, the problem of productivity realization of modern varieties, due to the more effective use of elements of intensification, becomes more relevant.

In conditions of climate change in the direction of global warming, the optimization of the sowing time of winter wheat is particularly important.

An analysis of researches of sowing time in the conditions of the region shows that there is a clear tendency to shift the optimal terms towards later ones. Thus, the best sowing dates for winter wheat in the 60 's and 70's of the 20th century were 5-15 of September, 80-90's - 15-25 of September. The beginning of the 21 st century is characterized by a shift of optimal terms of sowing by the end of September - the beginning of October (table 2).

Experimental data obtained by us indicate a significant effect of the sowing time on the growth and development of winter wheat plants and the formation of their productivity. This effect is largely due to changes in weather and climatic conditions, which requires the correction of the technology of winter wheat growing. In particular, for early sowing, it is necessary to foresee an increase in the cost of plant protection products from diseases and pests in the autumn period. In later sowing (second to third decades of October), under severe winter conditions, such as in 2003, the risk of freezing of crops increased. Thus, the optimal sowing time of winter wheat in the region is the third decade of September, admissible - no later than 10 of October [11]. 
2. Yield of winter wheat, depending on the sowing time, $t /$ ha

\begin{tabular}{|c|c|c|c|c|c|c|c|c|}
\hline \multirow[t]{3}{*}{ Sowing time } & \multicolumn{8}{|c|}{ Years of research } \\
\hline & \multicolumn{2}{|c|}{ 1991-1993 } & \multicolumn{2}{|c|}{ 2003-2005 } & \multicolumn{2}{|c|}{ 2006-2008 } & \multicolumn{2}{|c|}{ 2009-2011 } \\
\hline & yield & $\begin{array}{c} \pm \text { to } \\
\text { control }\end{array}$ & yield & $\begin{array}{c} \pm \text { to } \\
\text { control }\end{array}$ & yield & $\begin{array}{c} \pm \text { to } \\
\text { control }\end{array}$ & yield & $\begin{array}{c} \pm \text { to } \\
\text { control }\end{array}$ \\
\hline $\begin{array}{c}15 \text { of } \\
\text { September }\end{array}$ & 6,98 & - & 6,44 & - & 3,88 & - & 4,83 & - \\
\hline $\begin{array}{c}25 \text { of } \\
\text { September }\end{array}$ & 6,90 & $-0,08$ & 6,06 & $-0,38$ & 4,23 & 0,35 & 5,51 & 0,68 \\
\hline 5 of October & 6,34 & $-0,64$ & 5,65 & $-0,79$ & 4,87 & 0,99 & 5,34 & 0,51 \\
\hline 15 of October & 5,90 & $-1,08$ & 5,32 & $-1,12$ & 4,49 & 0,61 & 5,06 & 0,23 \\
\hline 25 of October & - & - & - & - & 4,26 & 0,38 & 4,94 & 0,11 \\
\hline
\end{tabular}

Realization of the potential of modern varieties results in increased uptake of not only nitrogen, phosphorus and potassium from the soil but also other elements of nutrition. In connection with the reduction of manure and the practical exclusion of simple fertilizers in fertilization systems (superphosphate, potassium magnesia, etc.), intensive depletion of soils on such important elements of plants nutrition as magnesium and sulfur observed, this requires their mandatory application in the winter wheat fertilization system. This is confirmed by our studies carried out on shallow low-humic chernozem typical. At the application of the calculated norm of mineral fertilizers for the planned grain yield of 8.0 t/ha, the complex application of magnesium and sulfur contributed to the increase in yield of winter wheat by $11 \%$ compared with the background, where it was at the level of $6.75 \mathrm{t} / \mathrm{ha}$ (table 3 ).

At the additional foliar microfertilizers application in the stem elongation phase, the yield increasing was at the level of $14 \%$. At the comparison of the efficiency of the application of magnesium and sulfur in the basal fertilizing and as additional fertilizing in the stem elongation phase tends to form higher yields at the basal fertilizing.

3. Yield of wheat winter depending on mineral nutrition (2011-2012), $t / h a$

\begin{tabular}{|l|c|c|c|}
\hline \multicolumn{1}{|c|}{ Fertilization } & \multirow{2}{*}{ Yield, t/ha } & \multicolumn{2}{c|}{ Divergence } \\
\cline { 3 - 4 } & & $\begin{array}{c}\text { from the } \\
\text { background }\end{array}$ & from the control \\
\hline Without fertilizers (control) & 2,96 & - & $-3,79$ \\
\hline $\begin{array}{l}\text { Norm of the NPP for the planned yield of } 8.0 \\
\text { t/ha - background }\end{array}$ & 6,75 & 3,79 & - \\
\hline Background +MgO in basal fertilizing & 7,18 & 4,22 & 0,43 \\
\hline Background + S in basal fertilizing & 6,98 & 4,02 & 0,23 \\
\hline Background + MgO + S in basal fertilizing & 7,47 & 4,51 & 0,72 \\
\hline $\begin{array}{l}\text { Background + MgSO by foliar application at } \\
\text { the beginning of stem elongation }\end{array}$ & 7,31 & 4,35 & 0,56 \\
\hline $\begin{array}{l}\text { Background + MgO +S in basal fertilizing + } \\
\text { foliar microfertilizers application at the end of } \\
\text { stem elongation }\end{array}$ & 7,68 & 4,72 & 0,93 \\
\hline
\end{tabular}

$$
\mathrm{LSD}_{05}
$$

One of the most important component of modern crop cultivation technologies is their reliable protection against harmful organisms. According to the results of our researches, the application of elements of integrated winter wheat protection provides a very significant increase in yield, especially at their complex application (table 4).

High efficiency of protection of vegetative plants is established. If, due to the addition of fungicidal seed treatment by insecticide, the yield increased by $4.6 \%$, then due to its additional application on this 
background during vegetation - by $16.2 \%$. Inclusion in the system of protection of vegetative plants treatment with fungicides caused the increase in grain yield to $7.27 \mathrm{t} / \mathrm{ha}$ compared with $5.31 \mathrm{t} / \mathrm{ha}$ on the control, or by $37.0 \%$. The obtained data indicate the high efficiency of the winter wheat protection system in the region. Its application is a prerequisite for the implementation of the potential of other elements of technology.

\section{Influence of intensification of plant protection system on the efficiency of winter wheat cultivation (2009-2011)}

\begin{tabular}{|c|c|c|c|}
\hline \multirow{2}{*}{ Plant protection system } & \multirow{2}{*}{ Yield, t/ha } & \multicolumn{2}{|c|}{ Increase in yield } \\
\hline & & t/ha & t/ha \\
\hline 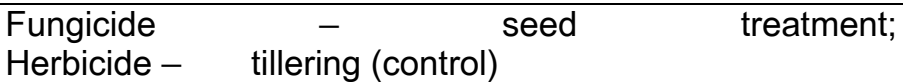 & 5,31 & - & - \\
\hline $\begin{array}{l}\text { Fungicide }+ \text { insecticide }- \text { seed treatment; } \\
\text { Herbicide - tillering }\end{array}$ & 5,55 & 0,24 & 4,6 \\
\hline $\begin{array}{l}\text { Fungicide + insecticide - seed treatment; } \\
\text { Herbicide - tillering; } \\
\text { Insecticide - during vegetation }\end{array}$ & 6,17 & 0,86 & 16,2 \\
\hline $\begin{array}{l}\text { Fungicide + insecticide - seed treatment; } \\
\text { Herbicide - tillering; } \\
\text { Insecticide - during vegetation; } \\
\text { Fungicide - during vegetation }\end{array}$ & 7,27 & 1,96 & 37,0 \\
\hline
\end{tabular}

\section{$\mathrm{LSD}_{05}$}

0,27

Intensification of the cultivation technology of winter wheat and other crops involves the comprehensive application of the latest scientific achievements in the context of each of its components. Due to the interaction effect, not only the progressive increase in yield, but also economic payback of technology, is achieved.

Conducted research found that at the intensification of technologies grain yield increased to $30-51 \%$ compared to conventional technology, where the yield was at the level of 4,64-5,25 t/ha (figure 1). Poliska 90 responded the least to the intensification of the technology, the yield of grain increased by 1.5 t/ha, or $30 \%$, while Favorytka and Voloshkova varieties provided the highest increase in yield at the level of 50 and $51 \%$, respectively. The highest yield of grain at the intensive technology formed the varieties Actor (7.27 t/ha), Voloshkova (7.19 t/ha) and Favoritka (7.14 t/ha).

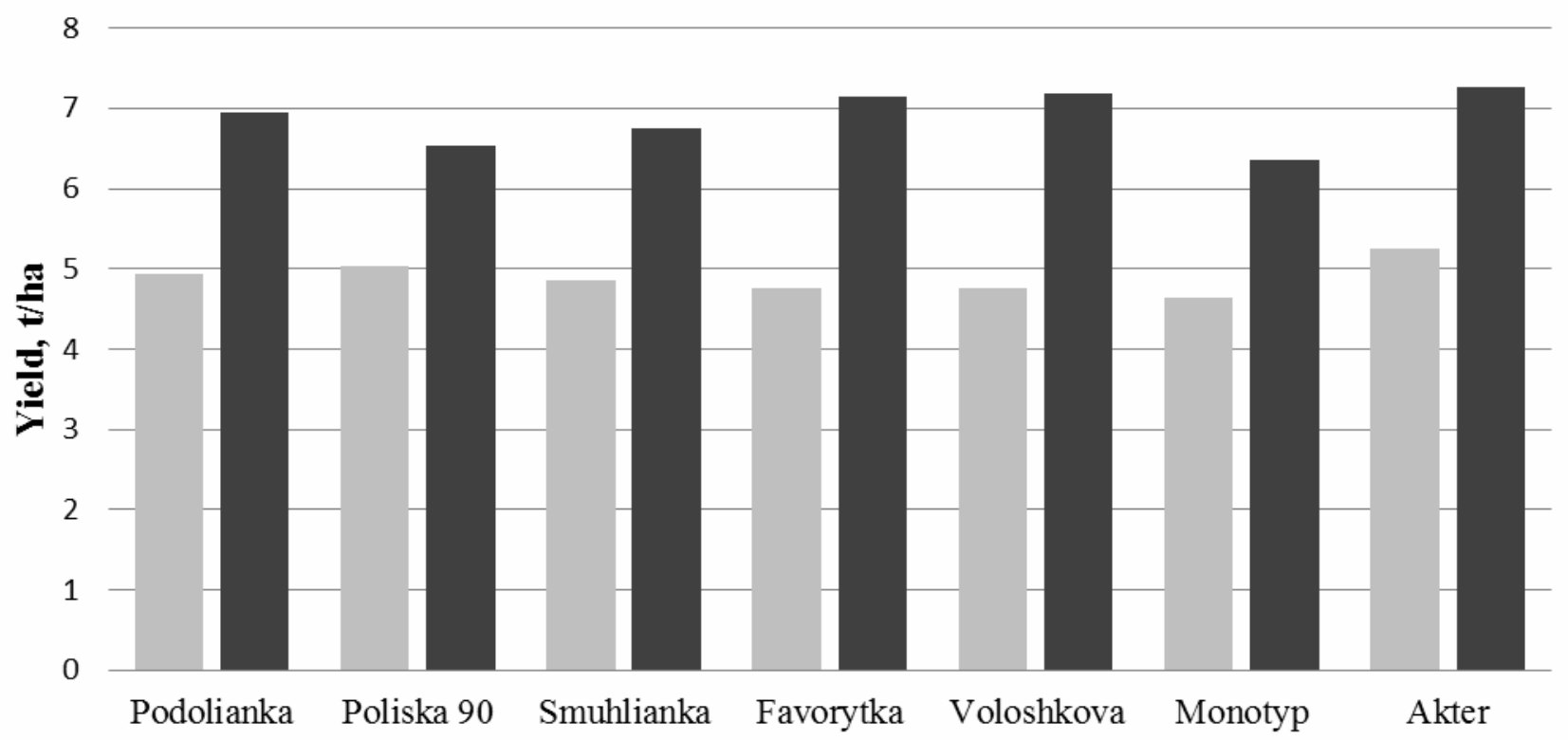

Fig.1 Influence of cultivation technology on yield of winter wheat varieties (2010-2012)

- Conventional technology $\quad$ Intensive technology 
An analysis of the economic efficiency of different levels of cultivation technology proves that at the current correlation between the prices of grain and the resources needed for its production, intensive technology provides the receipt of $14,144 \mathrm{UAH} /$ ha of operating profit, or 1,8 times larger than the conventional technology, creates economic prerequisites for the organization of production of European level, with a high culture of agriculture (table 5).

First of all, such high rates are achieved due to the increase in grain yield at the intensive technology compared to the conventional from 4.5 to $7.0 \mathrm{t} / \mathrm{ha}$, or 1.6 time larger.

5. Economic efficiency of different levels of technology of winter wheat cultivation (prices as of 01.01.2018)

\begin{tabular}{|c|c|c|c|c|}
\hline Technology & Yield, t/ha & $\begin{array}{c}\text { Expenses on } \\
\text { cultivation, } \\
\text { UAH/ha }\end{array}$ & $\begin{array}{c}\text { Cost of production, } \\
\text { UAH/ha }\end{array}$ & $\begin{array}{c}\text { Operating profit, } \\
\text { UAH/ha }\end{array}$ \\
\hline Conventional & 4,5 & 12205 & 20250 & 8045 \\
\hline Intensive & 7,0 & 17356 & 31500 & 14144 \\
\hline
\end{tabular}

Increasing the yields provided additional investment in fertilizers and plant protection products, resulting in their total expenses at the intensive technology increased to $17,356 \mathrm{UAH} / \mathrm{ha}$. Due to the lack of funds, many agricultural enterprises are not able to provide such technology expenses, which is one of the main reasons of relatively low yields and economic efficiency of winter wheat cultivation.

\section{Conclusions}

On average, in 2016-2018, the highest grain yield of winter wheat such as 8.31, 8.03, 7.79, 7.67 and $7.63 \mathrm{t} / \mathrm{ha}$ provided the varieties Kraievid, Odeska shchedrist, Odeska mudrist, Astarta, Economka, respectively.

Due to the processes of global warming, the optimal sowing time shifted from 15-25.09 in the 80's and 90 's of the XX century to $25.09-5.10$ - at the beginning of the XXI century.

At the additional magnesium, sulfur and microfertilizers application the yield increasing was at the level of $14 \%$. Inclusion in the system of protection of crops insecticide treatment of vegetative plants provided an increase in yield by $16,2 \%$, and insecticide and fungicides - by $37 \%$.

The integrated application of intensification factors in the technology of winter wheat cultivation such as high yield varieties, fertilization systems with application of sulfur, magnesium and microelements, integrated crop protection can increase the grain yield of winter wheat to $7.0 \mathrm{t} / \mathrm{ha}$ with a profit of 14144 $\mathrm{UAH} /$ hectare.

\section{References}

1. Kochmarskyi V.S. (2009). Napriamy pidvyshchennia efektyvnosti vyrobnytstva zerna v Ukraini. [Areas of increasing the efficiency of grain production in Ukraine]. Nauk.-tekhn. biul. Myronivskoho instytutu pshenytsi. Vyp. 9. P. 3 - 24. [In Ukrainian].

2. Lykhochvor V.V., Petrychenko V.F., Ivanchuk P.V. (2008). Zernovyrobnytstvo. [Grain production]. Lviv: NVF «Ukr. tekhnolohii». 624 p. [In Ukrainian].

3. Shelepov V.V. (2004). Morfologija, biologija, hozjajstvennaja cennost' pshenicy. [Morphology, biology, economic value of wheat]. Mironovka. 524 p. [In Russian].

4. Ulych L.I., Vasyliuk P.M. (2013). Urozhainyi potentsial ta adaptyvni vlastyvosti novykh sortiv pshenytsi miakoi ozymoi $v$ umovakh Lisostepu. [Crop potential and adaptive properties of new winter wheat varieties in the forest-steppe]. Visnyk ahrarnoi nauky. No 12. P. 25 - 28. [In Ukrainian]. 
5. Saiko V.F. (2004). Suchasni tekhnolohii vyroshchuvannia konkurentospromozhnoho zerna. [Modern technologies for growing competitive grain]. Zbirnyk naukovykh prats Instytutu zemlerobstva UAAN. Spetsvypusk. P. 26 - 31. [In Ukrainian].

6. Diter Shpaar. (2012). Zernovye kul'tury. Vyrashhivanie, uborka, hranenie i ispol'zovanie. [Cereals. Cultivation, cleaning, storage and use]. Kiev: Izd. dom «Zerno». 704 p. [In Russian].

7. Petrychenko V.F., Korniichuk O.V. (2018). Faktory stabilizatsii vyrobnytstva zerna pshenytsi ozymoi v Lisostepu Pravoberezhnomu. [Factors of Stabilization of Winter Wheat Grain Production in the RightBank Forest-Steppe]. Visnyk ahrarnoi nauky. No 2. P.17 - 23. [In Ukrainian].

8. Dennert J. (2007). Plus mit früher Spätdüngung. Bestandesführung Weizen. Dlz-agrarmagazin. No 5. $40-46 \mathrm{p}$.

9. Diepenbrock W., Ellmer F., Leon J. (2005). Ackerbau, Pflanzenbau und Pflan-zenzüchtung. Grundwissen Bachelor. Verlag Eugen Ulmer, Stuttgart. $366 \mathrm{~s}$.

10. Prots R. 100 ts/ha ozymoi pshenytsi - tse realnist. [100 ts / ha of winter wheat is a reality] Ahronom. 2013. No 4. P. 54 - 56. [In Ukrainian].

11. Lukashchuk L.la. (2012). Vplyv zminy klimatu na produktyvnist pshenytsi ozymoi zalezhno vid strokiv sivby. [Influence of climate change on the productivity of winter wheat depending on the timing of sowing] Visnyk Sumskoho natsionalnoho ahrarnoho universytetu. Seriia "Ahronomiia $i$ biolohiia». Vyp.9(24). P. 91 - 94. [In Ukrainian]. 